\title{
ASPEK KEAMANAN PADA KUALITAS FISIK FASILITAS BERMAIN ANAK TAMAN KOTA JANGGAN: MENUJU DENPASAR KOTA RAMAH ANAK
}

\author{
I Gede Wardana Putra ${ }^{1}$, Ni Ketut Agusintadewi ${ }^{2, *}$, Widiastuti ${ }^{3}$ \\ ${ }^{1,2,3}$ Program Studi Magister Arsitektur, Fakultas Teknik, Universitas Udayana \\ Jalan P.B. Sudirman, Denpasar, Bali 80234 \\ *E-mail koresponden: nkadewi@unud.ac.id
}

Diterima: 10-01-2021 Direview : 14-06-2021 Direvisi : 06-08-2021 Disetujui: 15-08-2021

\begin{abstract}
ABSTRAK. Taman kota sudah seharusnya memperhatikan salah satu aspek convivial, yaitu aspek keamanan. Aspek ini berpengaruh bagi keselamatan pengunjung, terutama anak-anak. Taman Kota Janggan yang terletak di Kota Denpasar memiliki fasilitas bermain anak, tetapi belum diketahui apakah kualitas fasilitas bermain tersebut telah memenuhi tingkat keamanan. Tujuan penelitian adalah untuk mengevaluasi kualitas fisik fasilitas bermain anak berdasarkan aspek keamanan pada taman kota tersebut. Metode kuantitatif digunakan dengan analisis skoring. Analisis skoring dilakukan berdasarkan kondisi fisik yang ada dan dinilai berdasarkan standar penilaian komponen pengendalian perancangan taman bermain anak menurut komponen dan kriteria penilaian keamanan fasilitas ruang bermain anak dari Baskara dan del Alamo. Komponen ini terdiri atas lokasi fasilitas, tata letak, peralatan permainan, konstruksi, dan material. Hasil penelitian menunjukkan bahwa secara rata-rata, persentase yang didapatkan yaitu $74 \%$. Dengan kata lain, fasilitas bermain anak di Taman Kota Janggan telah memenuhikualitas fisik dalam aspek keamanan bagi anak-anak, sehingga taman kota ini dapat digunakan sebagai lingkungan belajar bagi anak usia dini dengan model pembelajaran di luar kelas. Taman Kota Janggan yang layak anak ini menjadi salah satu indikator Kota Denpasar Ramah Anak.
\end{abstract}

Kata kunci:aspek keamanan, fasilitas bermain anak, kualitas fisik, taman kota ramah anak

ABSTRACT. City parks should pay attention to the social aspects, namely the safety aspect for children. Taman Kota Janggan, which is located in Denpasar City, has a children's playground. Nevertheless, it is unknown whether the quality of the game has met the level of safety. The study evaluated children's play facilities' physical quality based on the city park's safety aspects. The research method used was a scoring analysis that was carried out based on existing physical conditions. A set of requirements determined by the assessment criteria for children's play facilities from Baskara and Alamo: location, layout, game equipment, construction, and materials. An average scoring for children's safety obtained is $74 \%$. It means the children's play facilities in Janggan City Park have met the physical quality of children's safety. This city park can be used as a learning environment for early childhood with a learning model outside the classroom. The Janggan City Park is one of Denpasar's indicators that it is a Child-Friendly City.

Keywords: safety aspect, children's playground, physical quality, child-friendly city park

\section{PENDAHULUAN}

Pembangunan fisik kawasan perkotaan mengalami perkembangan dari waktu ke waktu. Pembangunan fisik tersebut mengubah ruang terbuka menjadi ruang terbangun (Rahmy et al., 2012). Ruang terbuka memiliki peran yang penting dalam mengendalikan kualitas lingkungan perkotaan (Handoyo et al., 2016). Tiga unsur penting ruang terbuka publik sebagai sebagai pengikat struktur ruang kota, yaitu manusia dan segala kegiatannya, alam sebagai tempat manusia beraktivitas, dan ruang pada alam yang dimanfaatkan oleh manusia (Darmawan, 2007).

Kondisi lingkungan kota dapat dipertahankan dengan menyediakan taman kota yang berkualitas dalam jumlah yang cukup. Jika ada keterbatasan lahan, kualitas fisik taman kota dapat ditingkatkan sebagai ruang terbuka publik. Ruang terbuka publik dapat menjadi tempat interaksi kultural dan ideologi, transaksi dagang, pertukaran ide dan sumber hiburan untuk masyarakat (Setiawan et al., 2014). Bagi Ardani et al., (2016), ruang terbuka publik perkotaan dapat dimanfaatkan untuk berbagai aktivitas sosial sampai aktivitas ekonomi.

Sebagai ruang terbuka publik, taman kota memberikan fungsinya untuk penduduk suatu kota atau atau bagian wilayah kota (Imansari \& Khadiyanta, 2015). Ruang publik yang ideal harus memiliki aspek convivial yaitu nyaman, aman, dan bisa menjadi wadah bagi masyarakat untuk berinteraksi satu dengan 
yang lainnya (Shaftoe, 2008). Keamanan merupakan persyaratan pemenuhan kepuasan masyarakat terhadap ruang publik (Nasution \& Zahrah, 2017).

Ruang publik dapat dikunjungi masyarakat segala usia. Usia rawan yang membutuhkan perhatian lebih saat beraktivitas pada taman kota yaitu usia anak-anak, sehingga taman kota hendaklah memenuhi persyaratan keamanan bagi anak-anak (Rahmiati \& Prihastomo, 2018). Cedera pada anak-anak dapat terjadi ketikan bermain karena penggunaan bahan yang kurang aman atau desain permainan yang membahayakan (Baskara, 2011). Cedera dapat berupa patah tulang, memar/lecet, keseleo, bahkan gegar otak (Vollman et al., 2009), dan yang terberat adalah cedera di kepala (Norton et al., 2004). Tidak hanya untuk perkembangan psikomotorik anak, ruang bermain sebaiknya dapat mendorong perkembangan kognisi anak (Chawla, 2011).

Ruang publik ramah anak haruslah memenuhi persyaratan sebagai taman terbuka publik yang dilengkapi dengan wahana permainan yang menarikuntuk tumbuh kembang anak, (Hernowo \& Navastara, 2017). Ruang bermain yang sesuai dengan anak juga dilengkapi dengan fasilitas bermain segala usia, memiliki aksesibilitas yang mudah, terdapat vegetasi dan sebagai tempat berkumpul (Veitch et al., 2007). Interaksi anak dengan alam membuktikan bahwa kegiatan ini cukup efektif menurunkan keterlibatan anak-anak pada aktivitas negatif dan asusila di masyarakat (Matsuoka, 2010). Ruang bermain anak harus dirancang agar sesuai dengan anak-anak, sehingga mereka dapat menjelajahi lingkungannya dengan bebas, bermain dan berinteraksi dengan teman-temannya (Riggio, 2002). Taman kota sebaiknya memiliki aspek convivial, khususnya dalam aspek keamanan bagi pengunjung terutama bagi usia rawan, seperti anak-anak karena terkait dengan keselamatan. Upaya meningkatkan aspek keamanan bagi anak-anak di taman kota perlu memperhatikan ruang bermain yang menjadi tempat anak beraktivitas.

Taman Kota Janggan merupakan salah satu ruang publik di Kota Denpasar.Salah satu fasilitas yang ada di taman kota ini yaitu ruang bermain anak. Upaya mewujudkan ruang publik yang memiliki aspek convivial, khususnya bagi anak-anakperlu memperhatikan aspek keamanan yang ada di fasilitas ruang bermain anak tersebut. Namun demikian, sampai saat ini belum diketahui tingkat keamanan yang ada di Taman Kota Janggan, khususnya pada fasilitas bermain anak dan belum terdapat penelitian untuk menilai kualitas fisik fasilitas bermain anak dalam aspek keamanan. Tujuan penelitian adalah menganalisis sejauh mana kualitas fisik fasilitas bermain anak dilihat dari aspek keamanan bagi pengunjung anak-anak Taman Kota Janggan. Apakah Taman Kota Janggan telah layak sebagai tempat media belajar bagi tumbuh kembangnya anak usia dini di Kota Denpasar? Penyediaan taman kota yang memperhatikan aspek keamanan dan keselamatan anak merupakan indikator Kota Layak Anak.

\section{METODE PENELITIAN}

\section{Lokasi Penelitian}

Taman Kota Janggan terletak di Jalan Raya Puputan 10, Kota Denpasar, Provinsi Bali, lihat Gambar 1. Taman ini memiliki luas sebesar $4.425 \mathrm{~m}^{2}$ dan diresmikan pada tanggal 6 Januari 2017 oleh Wakil Gubernur Provinsi Bali pada saat itu Drs. I Ketut Sudikerta.

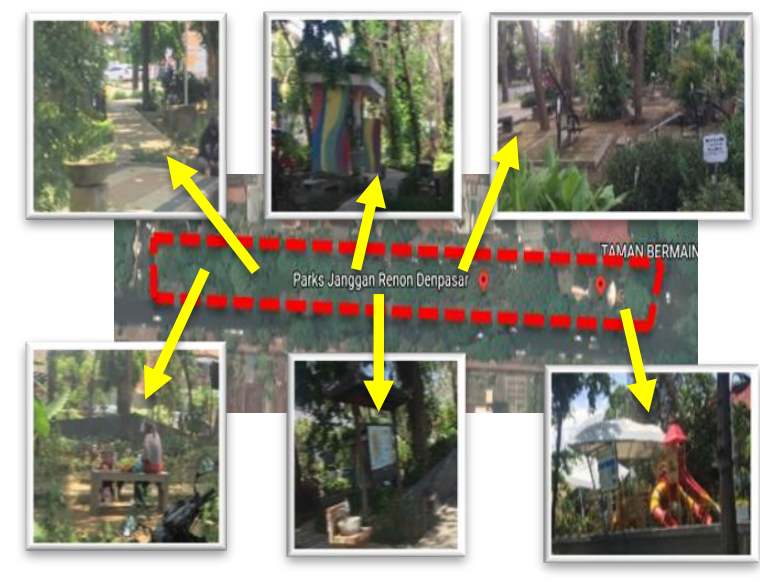

Gambar 1. Lokasi penelitian

(Sumber: observasi lapangan, Oktober 2020)

\section{Komponen dan Kriteria Penilaian}

Metode penelitian menggunakan metode kuantitatif dengan teknik analisis skoring dengan cara memberikan nilai pada kondisi yang ada di lapangan berdasarkan penilaian yang telah ditentukan (Mulyana, 2005). Objek yang akan dianalisis yaitu kualitas fisik fasilitas bermain anak yang terdapat pada Taman Kota Janggan.

Fasilitas ruang bermain anak diskoring berdasarkan kondisi fisik fasilitas secara riil dan disesuaikan dengan standar penilaian 
yang digunakan. Alamo (2002) merumuskan beberapa komponen pengendalian perancangan taman bermain, yang dirinci kembali secara detail berupa kriteria oleh Baskara (2011) menjadi prinsip pengendalian perancangan taman bermain anak di ruang publik. Komponen dan kriteria tersebut dijabarkan pada Tabel 1.

Tabel 1. Komponen dan kriteria keamanan fasilitas ruang bermain anak

\begin{tabular}{lll}
\hline No $\begin{array}{l}\text { Komponen } \\
\text { (Alamo, } \\
\text { 2002) }\end{array}$ & Kriteria (Baskara, 2011) \\
\hline 1 & Lokasi & - Pembatasan jumlah akses \\
& & masuk ke lokasi bermain \\
& & untuk memudahkan penga- \\
& & wasan pada anak-anak ter- \\
& & hadap gangguan fisik dan \\
& & kejahatan.
\end{tabular}

- Adanya pagar yang dapat membatasi pergerakan anak dari dan ke dalam area taman bermain.

- Pemilihan lokasi memungkinkan anak-anak seminimal mungkin tidak mendapatkan gangguan saat menuju lokasi.

2 Tata Letak - Taman bermain anak dirancang berdasarkan pengelompokkan aktivitas bermainaktif-pasif, kelom-pok umur, dan jenis permainan Adanya pemi-sahan bertujuan untuk mengurangi ketergangguan antar kelompok bermain.

- Ruang bermain diletakkan berdasarkan pergerakan anak dan meminimalkan cedera terutama untuk peralatan permainan yang bergerak, seperti ayunan, jungkatjungkit.

- Tata letak taman bermain memungkinkan kemudahan pengawasan anak yang sedang bermain oleh orang tua dan pendamping

3 Peralatan - Bahan alas permainan da-pat permainan meminimalkan bentur-an saat anak terjatuh ketika bermain.

- Membatasi ukuran maksimum dan minimum ruang gerak pada peralatan bermain.

- Adanya perlindungan pada bagian samping dan bawah untuk permainan yang memiliki perbedaan ketinggian dengan permukaan alas.

- Menghindari rancanganpermainan anak yang berisiko menimbulkan kecelakaan (terjepit).

\begin{tabular}{|c|c|c|}
\hline 4 & Konstruksi & $\begin{array}{l}\text { - Konstruksi taman bermain } \\
\text { sesuai standar SNI. } \\
\text { - Sambungan peralatan per- } \\
\text { mainan dipasang } \\
\text { untukmenghindari tonjolan } \\
\text { yang dapat melukai anak. }\end{array}$ \\
\hline 5 & Material & $\begin{array}{l}\text { - Bahan bertekstur halus, } \\
\text { terutama yang langsung } \\
\text { bersentuhan dengan kulit } \\
\text { anak-anak dengan intensitas } \\
\text { tinggi. } \\
\text { - Bahan pijakan kaki tidak licin } \\
\text { ketika anak-anak bermain. } \\
\text { - Bahan pegangan tangan tidak } \\
\text { licin dan berukuran yang } \\
\text { sesuai dengan ukuran tangan } \\
\text { untuk berpegangan secara } \\
\text { kuat. } \\
\text { Bagian pinggir atau pojokan } \\
\text { memiliki kelengkungan tinggi } \\
\text { dan tidak tajam atau bersudut, }\end{array}$ \\
\hline
\end{tabular}

Sumber: (Alamo, 2002; Baskara, 2011)

Tabel komponen dan kriteria dilengkapi dengan nama fasilitas yang dianalisis, kemudian diberi nilai berdasarkan tingkat kesesuaiannya. Penilaian dilakukan dengan memberikan nilai 1 untuk komponen dan kriteria yang memenuhi dan nilai 0 untuk komponen dan kriteria yang tidak memenuhi. Hasil analisis observasi menggunakan skala penilaian (rating scale), sebagaimana Tabel 2.

Tabel 2. Rating scale

\begin{tabular}{lll}
\hline No & Nilai & Kriteria \\
\hline 1 & 0 & Tidak memenuhi \\
2 & 1 & Memenuhi \\
\hline
\end{tabular}

Penilaian kualitas fisik dilakukan setelah nilai dari setiap komponen dan indikator diketahui. Klasifikasi dilakukan dengan mengkonversikan nilai kesesuaian ke dalam bentuk persentase (Sugiyono, 2006).

Persentase kesesuaian $=\frac{\text { nilai } \text { kesesuaian }}{\text { nilai maksimal }} \times 100 \%$

Interval penilaian berdasarkan persentase terhadap kualitas fisik fasilitas bermain anak di taman kota dalam aspek keamanan sebagai berikut:

$\begin{array}{lll}\text { Indeks } 0 \%-19,99 \% & : & \begin{array}{l}\text { Sangat } \\ \text { meme-nuhi }\end{array} \\ \text { Indeks } 20 \%-39,99 \% & : & \text { Tidak memenuhi } \\ \text { Indeks } 40 \%-59,99 \% & : & \text { Standar } \\ \text { Indeks } 60 \%-79,99 \% & : & \text { Memenuhi } \\ \text { Indeks } 80 \%-100 \% & : & \text { Sangat memenuhi }\end{array}$




\section{HASIL DAN PEMBAHASAN}

\section{Kondisi Fisik Fasilitas Taman Kota}

Ruang bermain anak di Taman Kota Janggan terdiri atas fasilitas bermain ayunan, fasilitas bermain jungkat-jungkit, rumah playground, seating area, dan kolam pasir. Penilaian aspek keamanan pada ruang bermain dengan mengevaluasi lokasi, tata letak (layout), peralatan permainan, konstruksi, dan material yang digunakan pada setiap fasilitas. Kondisi fisik pada setiap fasilitas pada Taman Kota Janggan dapat dilihat pada sejumlah tabel dan gambar berikut.

Tabel 2. Kualitas fisik rumah playground Komponen Kondisi Fisik

Evaluasi

Lokasi

- Akses masuk fasilitas bermain hanya satu, sehingga memudahkan kontrol.

- Terdapat pagar pembatas.

- Penempatan lokasi fasilitas berseberangan langsung dengan jalan raya.

Tata Letak - Terdapat jarak aman dengan fasilitas lain.

- Orang tua mudah mengawasi dari area pagar.

Peralatan Dilengkapi alas berbahan lembut.

- Pengaturan dimensi sesuai pengguna.

- Dilengkapi pengaman samping untuk area yang tinggi.

- Desain fasilitas tidak berisiko bagi anak.

Konstruksi Belum dilengkapi keterangan standar SNI

- Tidak terdapat tonjolan pada sambungan yang ada.

Material Permukaan memiliki tekstur yang halus.

- Bahan pijakan tidak licin

- Tidak menggunakan sudut yang tajam.

Tabel 3. Kualitas fisik ruang ayunan

\begin{tabular}{ll}
\hline $\begin{array}{l}\text { Komponen } \\
\text { Evaluasi }\end{array}$ & Kondisi Fisik \\
\hline Lokasi & - Akses masuk fasilitas bermain \\
& hanya satu, sehingga memudah- \\
& kan kontrol. \\
& - Terdapat pagar pembatas. \\
& - Penempatan lokasi fasilitas berse- \\
& berangan langsung dengan jalan \\
& raya. \\
Tata Letak & Belum memiliki jarak aman \\
& dengan fasilitas lain karena \\
& berdekatan dengan pintu masuk \\
& dan jalur pengguna. \\
& Orang tua mudah mengawasi dari \\
\hline
\end{tabular}

area pagar.

Peralatan - Dilengkapi alas berbahan lembut.

- Pengaturan dimensi sesuai pengguna.

- Dilengkapi pengaman samping untuk area yang tinggi.

- Desain fasilitas tidak berisiko bagi anak.

Konstruksi - Belum dilengkapi keterangan standar SNI

- Masih terdapat tonjolan pada sambungan yang ada.

Material - Permukaan memiliki tekstur yang halus dan terbuat dari besi, sehingga licin dan keras.

- Bahan pijakan tidak licin, tetapi pegangan terbuat dari besi, sehingga mudah licin.

- Tidak menggunakan sudut yang tajam.

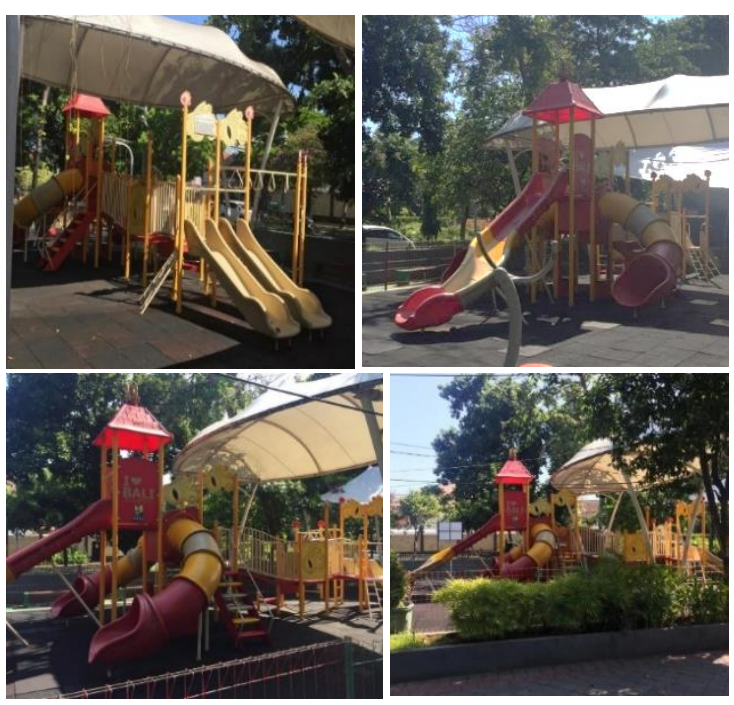

Gambar 2. Rumah play-ground

(Sumber: observasi lapangan, Oktober 2020)

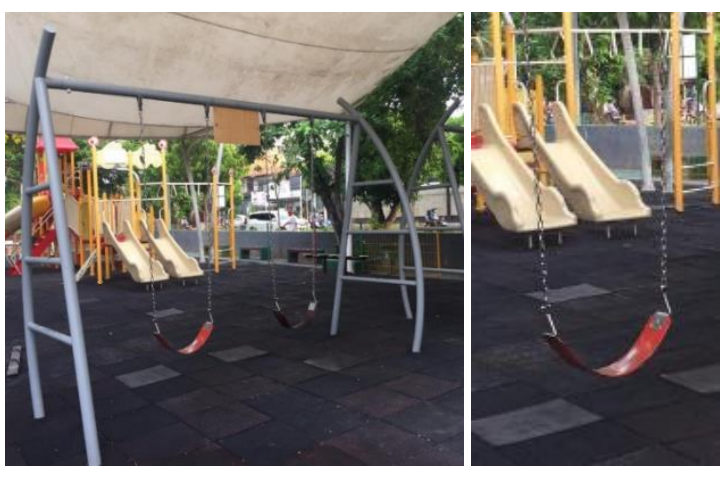

Gambar 3. Ruang ayunan

(Sumber: observasi lapangan, Oktober 2020) 
Tabel 4. Kualitas fisik ruang jungkat-jungkit Komponen Kondisi Fisik

Evaluasi

Lokasi

- Akses masuk fasilitas bermain hanya satu, sehingga memudahkan kontrol.

- Terdapat pagar pembatas.

- Penempatan lokasi fasilitas berseberangan langsung dengan jalan raya.

Tata Letak - Belum memiliki jarak aman dengan fasilitas lain karena berdekatan dengan pintu masuk dan jalur pengguna.

- Orang tua mudah mengawasi dari area pagar.

Peralatan - Dilengkap alas berbahan lembut.

- Pengaturan dimensi sesuai pengguna.

- Dilengkapi pengaman berupa pegangan tangan

- Desain fasilitas masih berisiko bagi anggota tubuh anak, sehingga anak berisiko terjepit.

Konstruksi - Belum dilengkapi dengan keterangan standar SNI

- Tidak terdapat tonjolan pada sambungan yang ada.

Material - Permukaan memiliki tekstur yang halus dan terbuat dari besi, sehingga licin dan keras.

- Bahan pijakan tidak licin, tetapi pegangan terbuat dari besi, sehingga mudah licin.

- Tidak menggunakan sudut yang tajam.

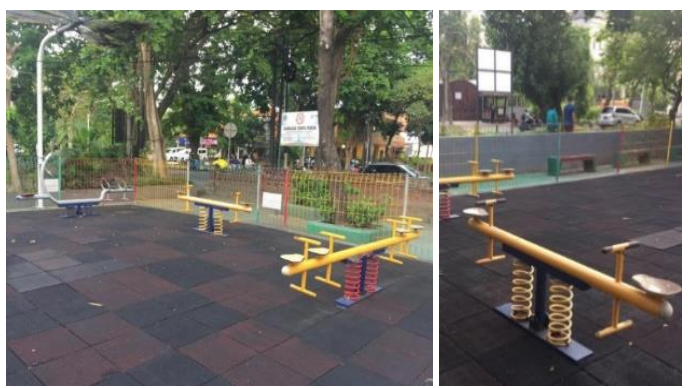

Gambar 4. Ruang jungkat-jungkit

(Sumber: observasi lapangan, Oktober 2020)

Tabel 5. Kualitas fisik kolam pasir

Kompone
Evaluasi
Lokasi

- Akses masuk fasilitas bermain hanya satu, sehingga memudahkan kontrol.

- Terdapat pagar pembatas, tetapi kurang tinggi bagi anak-anak.

- Penempatan lokasi fasilitas berseberangan langsung dengan jalan raya dan berdekatan dengan area cuci tangan pengunjung.

\begin{tabular}{|c|c|}
\hline Tata Letak & $\begin{array}{l}\text { - Belum memiliki jarak aman } \\
\text { dengan fasilitas lain karena } \\
\text { berdekatan dengan pintu masuk } \\
\text { dan jalur pengguna. } \\
\text { - Orang tua mudah mengawasi dari } \\
\text { area pagar. }\end{array}$ \\
\hline Peralatan & $\begin{array}{l}\text { - Pengaturan dimensi sesuai peng- } \\
\text { guna. } \\
\text { - Dilengkapi pengaman berupa pe- } \\
\text { gangan tangan } \\
\text { - Desain fasilitas masih berisiko } \\
\text { bagi anggota tubuh anak, } \\
\text { sehingga anak berisiko terjepit. }\end{array}$ \\
\hline Konstruksi & $\begin{array}{l}\text { - Belum dilengkapi keterangan stan- } \\
\text { dar SNI } \\
\text { - Tidak terdapat tonjolan pada sam- } \\
\text { bungan yang ada. }\end{array}$ \\
\hline Material & $\begin{array}{l}\text { - Permukaan memiliki tekstur yang } \\
\text { halus. } \\
\text { - Bahan pijakan tidak licin. } \\
\text { - Tidak menggunakan sudut yang } \\
\text { tajam. }\end{array}$ \\
\hline
\end{tabular}
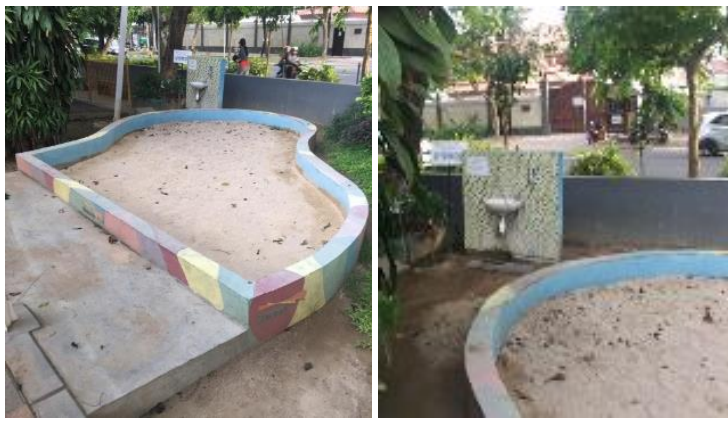

Gambar 5. Ruang kolam pasir

(Sumber: observasi lapangan, Oktober 2020)

Tabel 6. Kualitas fisik seating area

\begin{tabular}{|c|c|}
\hline $\begin{array}{l}\text { Komponen } \\
\text { Evaluasi }\end{array}$ & Kondisi Fisik \\
\hline Lokasi & $\begin{array}{l}\text { - Akses masuk fasilitas bermain } \\
\text { hanya satu, sehingga memudah- } \\
\text { kan kontrol. } \\
\text { - Terdapat pagar pembatas. } \\
\text { - Penempatan lokasi fasilitas berse- } \\
\text { berangan langsung dengan jalan } \\
\text { raya, berdekatan dengan tempat } \\
\text { sampah, dan akses pengunjung. }\end{array}$ \\
\hline Tata Letak & $\begin{array}{l}\text { - Belum memiliki jarak aman } \\
\text { dengan fasilitas lain karena } \\
\text { berdekatan dengan pintu masuk } \\
\text { dan jalur pengguna. } \\
\text { - Orang tua mudah mengawasi dari } \\
\text { area pagar. }\end{array}$ \\
\hline Peralatan & $\begin{array}{l}\text { - Dilengkapi alas berbahan lembut. } \\
\text { - Pengaturan dimensi sesuai peng- } \\
\text { guna. }\end{array}$ \\
\hline Konstruksi & $\begin{array}{l}\text { - Tidak terdapat tonjolan pada sam- } \\
\text { bungan. }\end{array}$ \\
\hline Material & $\begin{array}{l}\text { - Permukaan memiliki tekstur yang } \\
\text { halus dan bahan pijakan tidak } \\
\text { licin. } \\
\text { - Tidak menggunakan sudut yang }\end{array}$ \\
\hline
\end{tabular}




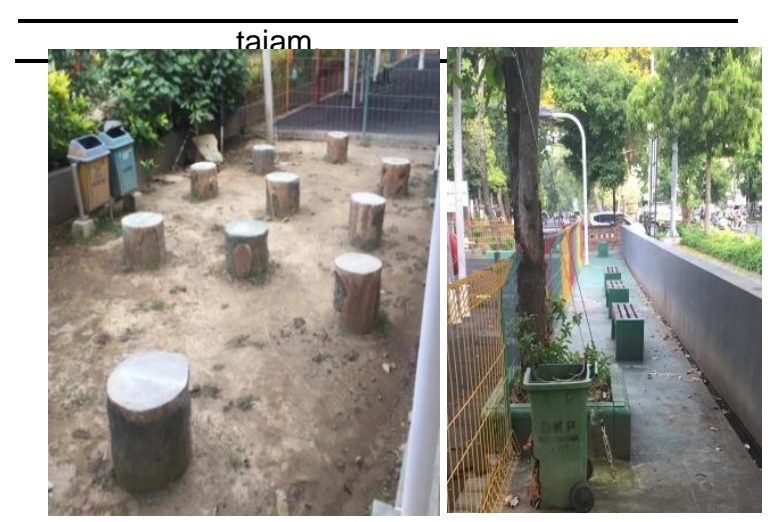

Gambar 6. Seating area

(Sumber: observasi lapangan, Oktober 2020)

\section{Hasil Penilaian terhadap Kualitas Fisik}

Dengan menggunakan kriteria dan komponen penilaian dan menganalisisnya dengan teknik scoring pada masing-masing fasilitas fisik Taman Kota Janggan, maka hasil penilaian dapat dilihat pada Tabel 7.

Tabel 7. Penilaian fasilitas bermain anak

\begin{tabular}{|c|c|c|c|c|c|c|c|}
\hline No & Komponen & Indikator & $\begin{array}{l}\text { Rumah } \\
\text { playgrou } \\
\text { nd }\end{array}$ & $\begin{array}{l}\text { Ruang } \\
\text { ayunan }\end{array}$ & $\begin{array}{l}\text { Ruang } \\
\text { jungkat- } \\
\text { jungkit }\end{array}$ & $\begin{array}{l}\text { Kolam } \\
\text { pasir }\end{array}$ & $\begin{array}{l}\text { Seating } \\
\text { area }\end{array}$ \\
\hline \multirow[t]{3}{*}{1} & Lokasi & - Akses masuk & 1 & 1 & 1 & 1 & 1 \\
\hline & & - Batas fisik & 1 & 1 & 1 & 0 & 0 \\
\hline & & - Penempatan lokasi & 0 & 0 & 0 & 0 & 0 \\
\hline \multirow[t]{3}{*}{2} & Tata Letak & - Zonasi & 1 & 1 & 1 & 1 & 1 \\
\hline & & - Peletakan fasilitas & 1 & 0 & 1 & 1 & 0 \\
\hline & & - Dapat diawasi & 1 & 1 & 1 & 1 & 1 \\
\hline \multirow[t]{4}{*}{3} & Permainan & - Area alas & 1 & 1 & 1 & 1 & 1 \\
\hline & & - Pengaturan dimensi & 1 & 1 & 1 & 1 & 1 \\
\hline & & $\begin{array}{l}\text { - Perlindungan samping } \\
\text { dan bawah }\end{array}$ & 1 & 1 & 1 & 1 & 1 \\
\hline & & $\begin{array}{l}\text { - Desain tidak berpotensi } \\
\text { melukai fisik }\end{array}$ & 1 & 1 & 0 & 1 & 1 \\
\hline \multirow[t]{2}{*}{4} & Kontruksi & $\begin{array}{l}\text { - Konstruksi memenuhi } \\
\text { standar SNI. }\end{array}$ & 0 & 0 & 0 & 1 & 1 \\
\hline & & - Sambungan peralatan & 1 & 0 & 1 & 1 & 1 \\
\hline \multirow[t]{7}{*}{5} & Material & - Tekstur bahan pelapis & 1 & 0 & 0 & 1 & 1 \\
\hline & & - Tekstur bahan pijakan & 1 & 1 & 1 & 1 & 1 \\
\hline & & - Bahan pegangan & 1 & 0 & 0 & 1 & 1 \\
\hline & & - Area sudutan & 1 & 1 & 1 & 0 & 1 \\
\hline & & Skor & 14 & 10 & 11 & 13 & 13 \\
\hline & & Nilai rata-rata & $87,5 \%$ & $62,5 \%$ & $68,7 \%$ & $81,2 \%$ & $81,2 \%$ \\
\hline & & Hasil & $\begin{array}{l}\text { Sangat } \\
\text { memenuhi }\end{array}$ & Standar & Memenuhi & $\begin{array}{l}\text { Sangat } \\
\text { meme- } \\
\text { nuhi }\end{array}$ & $\begin{array}{l}\text { Sangat } \\
\text { meme- } \\
\text { nuhi }\end{array}$ \\
\hline
\end{tabular}

Pada Tabel 7 memperlihatkan bahwa seluruh fasilitas bermain pada Taman Kota Janggan memiliki kualitas fisik di atas standar atau di atas $62,5 \%$. Analisis dari masing-masing ruang bermain sebagai berikut.

1. Rumah playground memiliki persentase $87,5 \%$ atau sangat memenuhi kriteria. Hanya dua indikator yang tidak memenuhi aspek keamanan bagi anak-anak, yaitu penempatan lokasi bermain yang dekat dengan jalan raya sangat membahayakan keselamatan anak-anak, meskipun telah diberi pagar pembatas. Selain itu, konstruksi permainan juga belum memenuhi standar SNI yang ditandai dengan belum tersedianya keterangan tentang standar SNI pada alat bermain tersebut.

Persentase kesesuaian $=\frac{14}{16} \times 100 \%=87,5 \%$

2. Ruang ayunan memiliki nilai $62,5 \%$ atau standar dan cukup memenuhi kriteria. Indikator yang belum terpenuhi kriteria adalah lokasi ruang ayunan yang berdekatan dengan jalan raya dan akses pengunjung. Konstruksi ayunan belum memenuhi standar SNI dan masih ada sambungan-sambungan yang dapat 
melukai anak-anak. Material yang digunakan berbahan licin dan tanpa bahan pelapis, sehingga dapat membahayakan anak-anak ketika menggunakan ayunan tersebut.

Persentase kesesuaian $=\frac{10}{16} \times 100 \%=62,5 \%$

3. Ruang jungkat-jungkit memiliki persentase $68,7 \%$ atau telah memenuhi standar. Indikator yang belum memenuhi standar keamanan bagi anak-anak adalah penempatan ruang ini yang dekat dengan jalan raya. Secara desain dan konstruksi, permainan ini cukup membahayakan bagi anak-anak karena permainan ini memungkinkan anak-anak terjepit. Sementara bahan yang digunakan juga kurang bertekstur atau kurang lembut dan licin.

Persentase kesesuaian $=\frac{11}{16} \times 100 \%=68,7 \%(3)$

4. Kolam pasir telah memenuhi kriteria karena memiliki skor $81,2 \%$. Indikator yang belum memenuhi standar yaitu pada pagar pembatas yang rendah, sehingga anakanak dapat memanjat dan meloncati pagar tersebut. Penempatan ruang bermain juga bersebelahan dengan area mencuci tangan, sehingga ruang bermain menjadi kurang higienis. Pada beberapa pinggiran ruang bermain, terdapat beberapa sudut tajam yang berpotensi melukai anak-anak.

Persentase kesesuaian $=\frac{13}{16} \times 100 \%=81,2 \%$

5. Seating area juga memiliki skor tinggi $(81,2 \%)$ atau telah memenuhi kriteria keamanan. Indikator yang tidak memenuhi kriteria adalah penempatan ruang ini yang bersebelahan dengan jalan raya dan tempat sampah. Selain membahayakan bagi keselamatan anak-anak, tempat sampah juga menimbulkan bau yang kurang sedap dan area ini menjadi kurang higienis.

Persentase kesesuaian $=\frac{13}{16} \times 100 \%=81,2 \%$

Sementara itu, secara rata-rata, persentase hasil penilaian untuk semua fasilitas ruang bermain pada Taman Kota Janggan yaitu $76,2 \%$.

Persentase kesesuaian $=\frac{61}{80} \times 100 \%=76,2 \%$
Dengan kata lain, fasilitas bermain anak di taman ini memenuhi kualitas fisik dalam aspek keamanan untuk pengunjung anak-anak. Maka, Taman Kota Janggan merupakan taman kota yang ramah pada anak dan dapat direkomendasikan sebagai salah satu lingkungan belajar bagi anak-anak usia dini di Kota Denpasar dan sekitarnya.

Tidak hanya sebagai ruang terbuka hijau, Taman Kota Janggan adalah taman terbuka publik yang menyediakan permainan untuk tumbuh kembang anak, juga menjadi sarana interaksi sosial bagi warga. Taman ini sebagai ruang publik terintegrasi yang mampu merangsang psikomotorik anak di luar ruang (Lestari \& Prima, 2020; Rizani et al., 2017). Maka dapat dikatakan bahwa taman kota ini merupakan salah satu sarana dan prasarana kota layak anak. Fungsi taman ini sesuai dengan karakteristik ruang publik terbuka ramah anak (RPTRA) yang dirumuskan oleh Hernowo dan Navastara (Hernowo \& Navastara, 2017).

Fungsi sosial ruang terbuka publik dapat tercapai jika memenuhi sifat responsif, demokratis, dan bermakna [9]. Sifat responsif terpenuhi apabila rancangan ruang terbuka publik dapat memenuhi berbagai kebutuhan penggunanya.keterlibatan secara aktif dan pasif, kenyamanan, dan relaksasi merupakan bentuk kepuasan warga kota dalam menggunakan ruang terbuka publik (Rahmiati \& Prihastomo, 2018). Taman Kota Janggan telah memenuhi kebutuhan anak-anak usia dini sebagai penggunanya atau telah memenuhi fungsi sosial tersebut.

Selain itu, penataan taman kota ramah anak juga perlu mempertimbangkan keberadaan pelaku usaha masyarakat di sekitarnya (Prasetyo, 2019). Letak Taman Kota Janggan berdekatan dengan Lapangan Monumen Bajra Sandhi sebagai ruang terbuka publik Kota Denpasar. Lapangan ini juga menyediakan area bagi berbagai pelaku usaha untuk berdagang makanan dan minuman ringan, berdagang mainan anak-anak, atau menawarkan jasa penyewaan permainan anak-anak. Maka, Taman Kota Janggan tidak hanya sebagai area rekreasi dan edukasi bagi pengguna anak-anak, tetapi juga memberi manfaat secara ekonomi bagi masyarakat sekitarnya.

\section{KESIMPULAN}

Menurut Kementerian Pemberdayaan Perempuan dan Perlindungan Anak (PPPA), 
bahan yang tidak membahayakan anak-anak, wahana permainan yang disesuaikan dengan kondisi anak, dan adanya sarana pendukung menuju ke area permainan merupakan salah satu kriteria ruang bermain ramah anak [9]. Berdasarkan hasil penilaian, Taman Kota Janggan telah layak dan aman bagi pengguna anak-anak.

Aspek keamanan dan keselamatan anak dalam penyediaan ruang terbuka publik menjadi indikator pemenuhan Kota Layak Anak (Tarigan \& lyati, 2018). Perencanaan Kota/Kabupaten Layak Anak (KLA) menjadi salah satu bentuk kemitraan antara pemerintah, masyarakat, dan swasta untuk pemenuhan hak-hak anak sebagai bagian dari komunitaskota (Herlina \& Nadiroh, 2018).

Taman Kota Janggandigunakan oleh warga Kota Denpasar sebagai tempat rekreasi keluarga dan sarana pembelajaran di luar ruangan untuk anak-anak. Taman kota inimerupakan media kemitraanbagiPemerintah Daerah, sekolah, dan masyarakat untuk pemenuhan hak anak. Taman Kota Janggan telah berperan menciptakansarana edukasi bagi anak usia dini melaluimetode pembelajaran di luar kelas.

\section{DAFTAR PUSTAKA}

Alamo, M. R. (2002). Design for Fun: Playgrounds. Barcelona: LINKS International.

Ardani, K. S. ... Iswari, R. (2016). Pemanfaatan Dan Pemaknaan Ruang Publik Bagi Masyarakat Di Kawasan Jalan Pahlawan Kota Semarang. Solidarity: Journal of Education, Society and Culture, 5(1), 40-48.

Baskara, M. (2011). Prinsip Pengendalian Perancangan Taman Bermain Anak Di Ruang Publik. Jurnal Lanskap Indonesia, 3(1), 27-34. https://doi.org/10.29244/jli.2011.3.1.\%p

Chawla, H. (2011). Introduction to Plant Biotechnology (Third Edit). https://doi.org/https://doi.org/10.1201/978 1315275369

Darmawan, E. (2007). Peranan Ruang Publik dalam Perancangan Kota (Urban Design) (p. 57). p. 57. Retrieved from http://eprints.undip.ac.id/347/1/edy_darm awan.pdf

Handoyo, F. ... Leksono, A. S. (2016). Analisis Potensi Ruang Terbuka Hijau Kota Malang Sebagai Areal Pelestarian Burung. J-Pal, 7(2), 86-95.
Herlina, N., \& Nadiroh. (2018). Peran Strategis Ruang Publik Terpadu Ramah Anak Dalam Rangka Pemenuhan Hak Anak Terhadap Lingkungan. JPUD - Jurnal Pendidikan Usia Dini, 12(1), 104-117. https://doi.org/10.21009//jpud.121.09

Hernowo, E., \& Navastara, A. M. (2017). Karakteristik Ruang Publik Terpadu Ramah Anak (RPTRA) Bahari di Kecamatan Cilandak Jakarta Selatan. Jurnal Teknik ITS, 6(2), C221-C224. https://doi.org/https://doi.org/10.12962/j23 373539.v6i2.25293

Imansari, N., \& Khadiyanta, P. (2015). Penyediaan Hutan Kota dan Taman Kota sebagai Ruang Terbuka Hijau (RTH) Publik Menurut Preferensi Masyarakat di Kawasan Pusat Kota Tangerang. Ruang, 1(3) $101-110$ https://doi.org/10.14710/ruang.1.3.101110

Lestari, P. I., \& Prima, E. (2020). Peran Ruang Publik Terpadu Ramah Anak Bagi Anak Usia Dini. Jurnal Obsesi: Jurnal Pendidikan Anak Usia Dini, 4(1), 483. https://doi.org/10.31004/obsesi.v4i1.396

Matsuoka, R. H. (2010). Student Performance and High School Landscapes: Examining the Links. Landscape and Urban Planning, $\quad 97(4), \quad$ 273-282. https://doi.org/https://doi.org/10.1016/j.lan durbplan.2010.06.011

Mulyana, D. (2005). IImu Komunikasi Suatu Pengantar. Bandung: Remaja Rosdakarya.

Nasution, A. D., \& Zahrah, W. (2017). Public Open Space's Contribution to Quality of Life: Does privatisation matters? Asian Journal of Environment-Behaviour Studies, 2(5), 71-83. https://doi.org/10.21834/aje-bs.v2i5.224

Norton, C. ... Sibert, J. R. (2004). Playground injuries to children. Archives of Disease in Childhood, 89(2), 103-108. https://doi.org/10.1136/adc.2002.013045

Prasetyo, A. (2019). Peningkatan Kualitas Taman Denggung Di Sleman Sebagai Taman Ramah Anak Melalui Pengembangan Kecerdasan Anak. Jurnal Arsitektur ARCADE, 3(3), 209. https://doi.org/10.31848/arcade.v3i3.283

Rahmiati, D., \& Prihastomo, B. (2018). Identifikasi Penerapan Konsep Ruang Publik Terpadu Ramah Anak (RPTRA) Pada Taman Kambang Iwak Palembang. Vitruvian, 8(1), 29. https://doi.org/10.22441/vitruvian.2018.v8 i1.004

Rahmy, W. A. ... Soeriaatmadja, A. R. (2012). Kebutuhan Ruang Terbuka Hijau Kota 
pada Kawasan Padat, Studi Kasus di Wilayah Tegallega, Bandung. Lingkungan Binaan Indonesia, 1(1), 2738.

Riggio, E. (2002). Child Friendly Cities: Good Governance in the Best Interests of the Child. Environment and Urbanization, 14(2), 45-58. https://doi.org/https://doi.org/10.1177/095 624780201400204

Rizani, E. N. ... Hernovianty, F. R. (2017). Klasifikasi Ruang Terbuka Hijau Taman Layak Anak di Kota Pontianak. Jurnal Mahasiswa Teknik Sipil Universitas Tanjungpura, 6(3), 2-5.

Setiawan, D. ... Burhan, A. (2014). The Public Space of Jogja Fashion Week Carnival and Cosplay Clothing in Yogyakarta. KOMUNITAS: International Journal of Indonesian Society and Culture, 6(2), 237-245.

https://doi.org/10.15294/komunitas.v6i2.3 303

Shaftoe, H. (2008). Convivial Urban Spaces: Creating Effective Public Places. London: Earthscan.

Sugiyono. (2006). Statistika untuk Penelitian. Bandung: CV Alfabeta.

Tarigan, L. A., \& lyati, W. (2018). Keamanan dan Keselamatan Anak pada Ruang Publik Terpadu Ramah Anak Kalijodo di Jakarta. Jurnal Mahasiswa Jurusan Arsitektur, 6(3). Retrieved from http://arsitektur.studentjournal.ub.ac.id/in dex.php/jma/article/view/654

Veitch, J. A. ... Newsham, G. R. (2007). A Model of Satisfaction with Open-plan Office Conditions: COPE field findings. Journal of Environmental Psychology, 27(3), 177-189. https://doi.org/https://doi.org/10.1016

Vollman, D. ... Smith, G. (2009). Epidemiology of Playground Equipment-Related Injuries to Children in the United States, 1996-2005. Clinical Pediatrics, 48(1), $66-71$. 
